\title{
Composite paraganglioma-ganglioneuroma of the urinary bladder: a rare neoplasm causing hemodynamic crisis at fumour resection
}

\author{
C-H. Chen, MD; ${ }^{*}$ Alexander H. Boag, MASc, MD; ${ }^{*}$ Darren T. Beiko, MD; ${ }^{\dagger} D$. Robert Siemens, MD, FRCSC; ${ }^{\dagger}$ \\ Alison Froese, MD, FRCPC; $\$$ Phillip A. Isotalo, MD, FRCPC*
}

\begin{abstract}
A 64-year-old man presented with gross painless hematuria. Cystoscopy revealed a submucosal bladder neck mass covered by normal urothelium. During transurethral resection, the patient developed hemodynamic crisis including sinus bradycardia. Histopathologic examination revealed a primary bladder composite paraganglioma-ganglioneuroma (CPG). The patient underwent partial cystectomy and is symptom-free after one year. Bladder CPGs are extremely rare neoplasms that may result in lifethreatening catecholamine secretion, especially during tumour manipulation. These tumours require complete surgical excision and should be included in the differential diagnosis of any solitary bladder mass covered by normal urothelium, especially when there is a history of hypertension or micturition attacks.
\end{abstract}

Can Urol Assoc J 2009;3(5):E45-E48

\section{Introduction}

Paragangliomas are uncommon neoplasms that can arise in extra-adrenal paraganglia or in the adrenal medulla, with the latter conventionally classified as pheochromocytomas. Extra-adrenal paragangliomas are usually intra-abdominal and arise around the renal hilum, the adrenal gland or organ of Zuckerkandl, but approximately $10 \%$ of these tumours occur in the urinary bladder and account for less than $0.5 \%$ of all primary bladder tumours. ${ }^{1-3}$ The clinical presentation of bladder paragangliomas classically consists of the triad of paroxysmal hypertension, gross painless hematuria and "micturition attacks" consisting of headache, palpitations, diaphoresis and blurred vision during or after voiding. ${ }^{3}$ However, in a series of bladder paragangliomas from the Mayo Clinic, gross hematuria and hypertension were the most common clinical presentations. ${ }^{4}$ Malignant behaviour has been documented in about $5 \%$ to $19 \%$ of bladder paragangliomas. ${ }^{1,4}$

We describe a 64-year-old man with an extremely rare primary composite paraganglioma-ganglioneuroma (CPG) of the urinary bladder who experienced significant hemodynamic instability during tumour resection. Surprisingly, postoperative serum and urine catecholamine levels were within normal limits. To our knowledge, this is only the sixth reported case of CPG of the urinary bladder ${ }^{3,5-8}$ and the first case to result in hemodynamic instability during tumour resection.

\section{Case report}

A 64-year-old man with well-controlled systemic arterial hypertension and type 2 diabetes mellitus was referred to our institution for a single episode of gross painless hematuria in the absence of other lower urinary tract symptoms. His personal and family histories were negative for urologic pathology, neurofibromatosis and multiple endocrine neoplasia syndrome. His baseline blood pressure $(120 / 65 \mathrm{~mm}$ $\mathrm{Hg}$ ) and pulse rate (65 to $75 \mathrm{bpm}$ ) were within normal limits.

Initial urine cytology revealed only a few red blood cells and urine culture was negative for microorganisms. Abdominal ultrasound revealed a partial cystic mass of the anterior bladder wall that measured $5 \times 4 \times 3 \mathrm{~cm}$. Adjacent structures, including the prostate, were not involved. Cystoscopy confirmed the presence of a well-circumscribed non-obstructive submucosal mass covered by smooth urothelium at the anterior bladder neck. This mass lacked the typical exophytic or ulcerative appearance of a urothelial carcinoma and the cytoscopic differential diagnosis included lymphoma and leiomyoma. During transurethral resection of the tumour under spinal anaesthesia, the patient manifested extreme blood pressure fluctuations (systolic 150/215 mm Hg; diastolic 80/125 mm Hg) with one episode of severe sinus bradycardia (heart rate dropped from 70 to $37 \mathrm{bpm}$ ). The patient's heart rate normalized with atropine but labile blood pressure persisted throughout the procedure. The tumour resection was incomplete due to tumour bulk and hemorrhage at resection. Post-tumour resection, the patient was monitored by telemetry for 24 hours and his vital signs returned to baseline values.

Histopathologic examination of the resected tumour revealed a paraganglioma composed of nests of mitotically quiescent polygonal cells with pink granular cytoplasm that were arranged in a characteristic Zellballen organoid growth 
pattern (Fig. 1). The tumour demonstrated a prominent vascular network typical of paraganglioma. The neoplasm extensively infiltrated the lamina propria and muscularis propria of the bladder. In addition, the tumour contained a large component of ganglioneuroma consisting of mature ganglion and spindle cells (Fig. 2) that had merged with the paraganglioma component. The paraganglioma tumour cells were strongly immunoreactive for chromogranin and synaptophysin and were negative for keratin immunostains, including high and low molecular weight cytokeratins and cytokeratins AE1/AE3. The ganglion cells within the ganglioneuroma component were immunoreactive for S-100 protein as were the sustentacular cells within the paraganglioma component. There was no evidence of a primitive

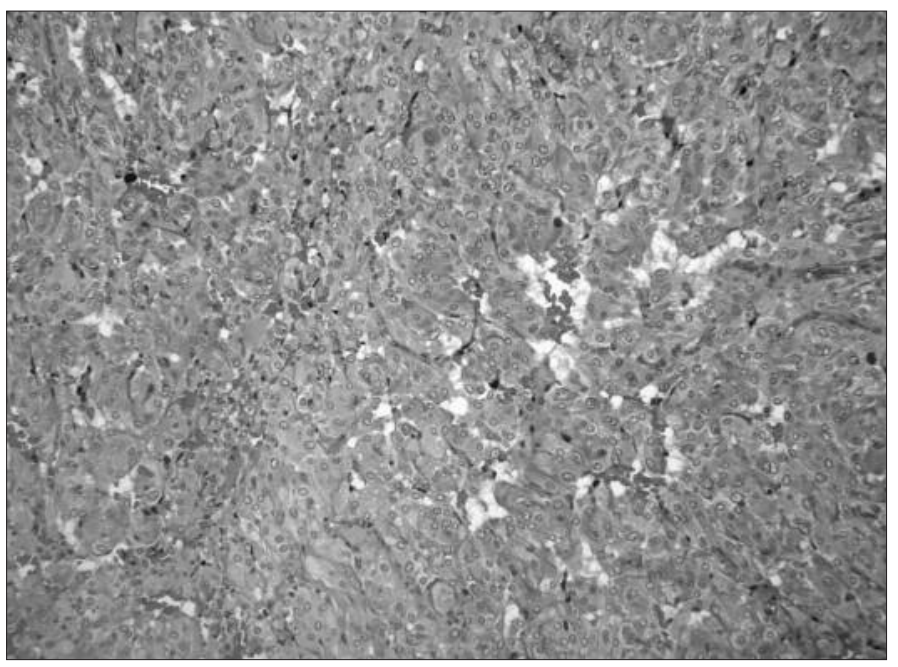

Fig. 1. Paraganglioma component of the composite paragangliomaganglioneuroma showing the typical Zellballen growth pattern of paraganglioma (hematoxylin-phloxine-saffron stain, 100x magnification).

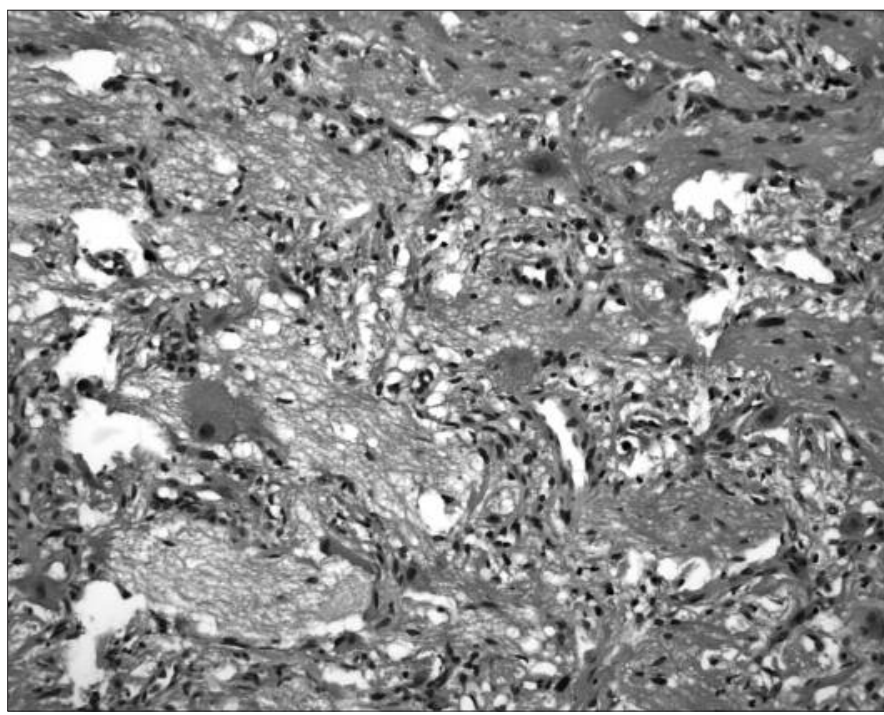

Fig. 2. Ganglioneuroma component of the composite paragangliomaganglioneuroma containing occasional and prominent ganglion cells (hematoxylin-phloxine-saffron stain, 100x magnification). neural component within the tumour. The patient was diagnosed with a CPG of the urinary bladder.

Further staging with computerized tomography and magnetic resonance imaging delineated a focus of residual tumour $1.8 \times 1.1 \times 3 \mathrm{~cm}$ anterior to the prostatic urethra within the bladder wall. There was no evidence of extravesical tumour extension and ${ }^{131} \mathrm{I}$-metaiodobenzylguanidine (MIBG) scintigraphy demonstrated no evidence of metastatic disease. Most interestingly, serum levels of catecholamines and 24-h urinary excretion of catecholamines, vanillylmandelic acid and metanephrines at postcytoscopic resection were all within normal limits. Preoperative serum and urine catecholamine/catecholamine metabolites were not measured. The patient underwent partial cystectomy under alpha1receptor blockade; the surgical specimen revealed residual paraganglioma-ganglioneuroma and appeared to be completely excised. He remains symptom-free 12 months after surgery with no evidence of tumour recurrence or metastatic disease.

\section{Discussion}

First described by Zimmerman et al. in $1953,{ }^{9}$ paragangliomas are rare neoplasms of the urinary bladder. These tumours are thought to arise from small persistent paraganglionic tissue nests that migrate into the bladder during development. ${ }^{9,10}$ Rare periprostatic paragangliomas have also been described. ${ }^{11-13}$ Malignant behaviour has been documented in $5 \%$ to $19 \%$ of bladder paragangliomas ${ }^{1,4}$ and there are no reliable histologic criteria to differentiate malignant from benign tumours. ${ }^{3,4}$ There is a suggestion that paragangliomas that result in necrosis, mitotic activity and angiolymphatic invasion behave more aggressively. ${ }^{14}$

Composite paraganglioma-ganglioneuromas of the bladder are even rarer than bladder paragangliomas and both tumours may present in a similar manner. To our knowledge, only 5 bladder CPGs have been previously reported and their salient clinical features are summarized in Table 1. 3,5-8 Like bladder paragangliomas, bladder CPGs can be biochemically functional and can release catecholamines, especially during tumour manipulation as occurred in our patient. ${ }^{5,6,8} \mathrm{~A}$ high index of clinical suspicion is necessary to preoperatively identify bladder paragangliomas and rarer CPGs. However, many of these tumours often present only with gross hematuria in the absence of hypertension or micturition attacks, making their preoperative identification difficult. ${ }^{4,5}$ Clinically suspected bladder paragangliomas and CPGs should be biopsied or resected under appropriate alpha-adrenergic blockade to prevent hemodynamic crises associated with tumour catecholamine release. Our patient developed significant hemodynamic instability and sinus bradycardia when his bladder CPG was initially resected in the absence of adrenergic blockade. Despite 


\begin{tabular}{|c|c|c|c|c|c|c|c|c|c|c|}
\hline Case & $\begin{array}{l}\text { Gen- } \\
\text { der }\end{array}$ & Age & $\begin{array}{c}\text { Clinical } \\
\text { presentation }\end{array}$ & $\begin{array}{l}\text { Hormone } \\
\text { levels }\end{array}$ & $\begin{array}{l}\text { Cystoscopic } \\
\text { appearance }\end{array}$ & $\begin{array}{l}\text { Tumor } \\
\text { location }\end{array}$ & $\begin{array}{l}\text { Size, } \\
\mathrm{cm}\end{array}$ & Treatment & $\begin{array}{c}\text { Follow-up, } \\
\text { mo }\end{array}$ & $\begin{array}{c}\text { Recurrence/ } \\
\text { metastasis }\end{array}$ \\
\hline $\begin{array}{l}\text { Lam et } \\
\text { al. }{ }^{5}\end{array}$ & $\mathrm{~F}$ & 81 & $\begin{array}{l}\text { Hematuria; No } \\
\text { hypertension }\end{array}$ & Not described & $\begin{array}{l}\text { Pedunculated } \\
\text { tumor with a } \\
\text { stalk }\end{array}$ & $\begin{array}{l}\text { Right } \\
\text { lateral } \\
\text { wall }\end{array}$ & 4.8 & $\begin{array}{l}\text { Transurethral } \\
\text { resection }\end{array}$ & 3 & None \\
\hline $\begin{array}{l}\text { Usuda } \\
\text { and } \\
\text { Emura }^{6}\end{array}$ & M & 73 & $\begin{array}{l}\text { Dysuria; No } \\
\text { hypertension }\end{array}$ & $\begin{array}{l}\text { Elevated serum } \\
\text { E/N; elevated } \\
\text { urinary V/C/M }\end{array}$ & $\begin{array}{l}\text { Solitary smooth } \\
\text { submucosal } \\
\text { nodule }\end{array}$ & $\begin{array}{l}\text { Left } \\
\text { bladder } \\
\text { wall }\end{array}$ & 4 & Partial cystectomy & 12 & None \\
\hline $\begin{array}{l}\text { Dundr } \\
\text { et al. }\end{array}$ & $\mathrm{F}$ & 70 & $\begin{array}{c}\text { Micturition attack } \\
\text { with paroxysmal } \\
\text { hypertension }\end{array}$ & $\begin{array}{l}\text { Elevated serum } \\
\text { E/N }\end{array}$ & $\begin{array}{l}\text { Solitary smooth } \\
\text { submucosal } \\
\text { nodule }\end{array}$ & $\begin{array}{l}\text { Base of } \\
\text { bladder }\end{array}$ & 6.5 & Radical cystectomy & 11 & None \\
\hline $\begin{array}{l}\text { Hurwitz } \\
\text { et al. }{ }^{8}\end{array}$ & $\mathrm{~F}$ & 49 & $\begin{array}{c}\text { Micturition } \\
\text { attack; No } \\
\text { hypertension }\end{array}$ & $\begin{array}{c}\text { Elevated urinary } \\
\text { V/C/M }\end{array}$ & $\begin{array}{c}\text { Spherical } \\
\text { submucosal } \\
\text { mass }\end{array}$ & $\begin{array}{l}\text { Right } \\
\text { lateral } \\
\text { wall }\end{array}$ & 3.5 & Partial cystectomy & $\begin{array}{c}\text { Not } \\
\text { described }\end{array}$ & None \\
\hline Current & M & 64 & $\begin{array}{c}\text { Hematuria; } \\
\text { Hemodynamic } \\
\text { crisis at resection }\end{array}$ & Negative & $\begin{array}{l}\text { Solitary smooth } \\
\text { submucosal } \\
\text { nodule }\end{array}$ & $\begin{array}{l}\text { Anterior } \\
\text { bladder } \\
\text { neck }\end{array}$ & 5 & Partial cystectomy & 12 & None \\
\hline
\end{tabular}

Leestma and Price3: Composite paraganglioma-ganglioneuroma identified pathologically without description of accompanying clinical features.

$\mathrm{F}=$ female; $\mathrm{M}$ = male; $\mathrm{E} / \mathrm{N}=$ =epinephrine/norepinephrine; $\mathrm{V} / \mathrm{C} / \mathrm{M}$ = vanillylmandelic acid/catecholamines/metanephrines.

our patient's undoubted catecholamine release with resulting hypertensive crisis during surgery, the patient's postoperative serum catecholamine levels and 24-h collection of urine catecholamines and metabolites were within normal limits. This result demonstrates that these tumours may show variable catecholamine secretion and may appear biochemically non-functional, making their preoperative identification difficult in some cases.

Due to their rarity, bladder paragangliomas can be confused histologically with urothelial carcinomas, especially the nested variant of urothelial carcinoma, and other tumours including bladder granular cell tumours, metastatic large cell neuroendocrine carcinoma and malignant melanoma., ${ }^{4,15}$ Appropriate immunohistochemical investigations and correlation with cytoscopic findings can aid in establishing a correct diagnosis, since vesical paragangliomas often present as solitary masses covered by normal urothelium. ${ }^{15}$

\section{Conclusion}

Like bladder paragangliomas, bladder CPGs should be treated with complete surgical excision. Although potentially malignant, the bladder paraganglioma series from the Mayo Clinic demonstrates that patients with T1 or T2 disease have favourable outcomes post-complete tumour resection. ${ }^{4}$ Patients with advanced disease (T3 or T4) were at risk of tumour recurrence and metastatic disease. To date, no bladder CPG has demonstrated malignant behaviour; however, follow-up is limited (Table 1) and all cases have been described as isolated reports. ${ }^{3,5-8}$ Due to the limited experience with these rare bladder tumours, it is best to regard bladder CPGs as potentially malignant neoplasms like their paraganglioma counterparts that require com- plete surgical excision and adequate clinical follow-up.

Composite paraganglioma-ganglioneuromas of the bladder may present without the "classic" clinical triad of paragangliomas (hypertension, gross hematuria and micturition attacks) and should be included in the differential diagnosis of any solitary bladder mass covered by normal urothelium. Like paragangliomas, bladder CPGs should be resected with adequate alpha-adrenergic blockade to prevent lifethreatening hemodynamic crisis.

*Department of Pathology and Molecular Medicine; 'Department of Urology; §Department of Anesthesiology, Kingston General Hospital and Queen's University, Kingston, ON

This paper has been peer-reviewed.

Competing interests: None declared.

\section{References}

1. Tischler AS, Komminoth P. Extra-adrenal sympathetic paraganglioma: cervical, intrathoracic and urinary bladder. In: Delellis RA, Lloyd RV, Heitz PU, Eng C, editors. World Health Organization Classification of Tumours. Pathology and Genetics of Tumours of Endocrine Organs. Lyon, France: IARC Press; 2004:165-6.

2. Grignon DJ. Neoplasms of the urinary bladder. In Bostwick DG, Eble JN, eds. Urologic Surgical Pathology. St. Louis, MO: Mosby-Year Book Inc.; 1997:214-305.

3. Leestma JE, Price EB Jr. Paraganglioma of the urinary bladder. Cancer 1971;28:1063-73.

4. Cheng L, Leibovich BC, Cheville JC, et al. Paraganglioma of the urinary bladder: Can biologic potential be predicted? Cancer 2000;88:844-52.

5. Lam KY, Loong F, Shek TWH, et al. Composite paraganglioma-ganglioneuroma of the urinary bladder: a clinicopathologic, immunohistochemical, and ultrastructural study of a case and review of the literature. Endocr Pathol 1998;9:363-73.

6. Usuda H, Emura I. Composite paraganglioma-ganglioneuroma of the urinary bladder. Pathol Int 2005;55: 596-601.

7. Dundr P, Dudorkinova D, Povysil C, et al. Pigmented composite paraganglioma-ganglioneuroma of the urinary bladder. Pathol Res Pract 2003;199:765-69. 
Chen et al.

8. Hurwitz R, Fitzpatrick T, Ackerman I, et al. A neuro-ectodermal tumor in the bladder. J Urol 1980;124: 417-21.

9. Zimmerman I, Biron R, MacMahon H. Pheochromocytoma of the urinary bladder. N Engl J Med 1953;249: 25-6.

10. Fletcher T, Bradley W. Neuroanatomy of the bladder-urethra. J Urol 1978;119:153-60.

11. Perlmutter AE, Livengood R, Zaslau S, et al. Periprostatic pheochromocytoma. Urology 2005;66:194.

12. Dennis PJ, Lewandowski AE, Rohner TJ, et al. Pheochromocytoma of the prostate: an unusual location. J Urol 1989;141:130-2.

13. Neilsen VM, Skovgard N, and Kvist N. Phaechromocytoma of the prostate. Br J Urol 1987:59:478-9.
14. Lack E, Cubilla A, Woodruff J. Paragangliomas of the head and neck region: a pathologic study of tumours from 71 patients. Hum Patho 1979;10:91-218.

15. Zhou M, Epstein II, Young RH. Paraganglioma of the urinary bladder: a lesion that may be misdiagnosed as urothelial carcinoma in transurethral resection specimens. Am J Surg Pathol 2004;28:94-100.

Correspondence: Dr. Phillip Isotalo, Department of Pathology and Molecular Medicine, Kingston General Hospital, 76 Stuart Street, Kingston, 0N K7L 2V7; fax 613-548-6076; isotalop@kgh.kari.net 